\title{
ABALONE POACHING: A PHILOSOPHICAL APPROACH
}

\author{
By Lauren Carr*
}

\section{Introduction}

The question that I raise is whether one's judgment, in other words, knowing the difference between right and wrong, can be clouded by monetary rewards, especially with regard to criminal activity. I take a philosophical approach with specific focus on the environmental concern of abalone poaching. ${ }^{1}$ I draw parallels and theoretical answers from Karl E Klare's 'Legal culture and transformative constitutionalism', 2 James Boyd White's 'Justice in tension: an expression of law and the legal mind', ${ }^{3}$ John Dugard's 'The judicial process, positivism and civil liberty' ${ }^{4}$ and the theories of judgment of Hannah Arendt. ${ }^{5}$

Environmental crime is a rising epidemic, especially in South Africa. I argue that not enough attention is paid to such crimes. Sensational crimes seem to have an increased popularity in the press and environmental crimes seem to go deprioritised. There appears to be very few viable solutions for crimes that yield great economic returns. In the mind of the offender, the motivation of great economic returns can be said to override the sense of morality or judgment.

\section{Judgment}

'Judgment' can be defined as 'the ability to make considered decisions or come to a sensible conclusion'. ${ }^{6}$ It is the tension between freedom and constraint. My approach towards interpreting the term 'judgment' is

Lauren Carr, BA Law University of Pretoria.

Abalone is an edible sea mollusk, in an ear-shaped shell lined with mother-ofpearl. http://www.http://oxforddictionaries.com/definition/english/abalone (accessed on 10 May 2013).

2 K Klare 'Legal culture and transformative constitutionalism' (1998) 14 South African Journal on Human Rights $146-172$.

J Boyd White 'Justice in tension: an expression of law and the legal mind' (2012) No Foundations: An Interdisciplinary Journal of Law and Justice 1-19.

4 J Dugard 'The judicial process, positivism and civil liberty' (1971) South African Law Journal 181-200.

5 D Villa (ed) The Cambridge Companion to Hannah Arendt (2005) 245-261. http: / / oxforddictionaries.com/definition/english/judgement?q=judgment (accessed 10 May 2013). 
a three-fold one. The first workings of judgment occur within the offender's conscience. There is a rebuttable presumption in the South African legal system that an individual is mentally sound unless proven otherwise. 7 To be 'mentally sound' would imply rationality and the presence of a conscience. In line with the question at hand, this notion implies that most crime is premeditated and considered, as it can be assumed that most individuals would know the difference between right and wrong. ${ }^{8}$ I will thus be following the assumption, as subscribed to by Arendt, that all people possess the ability to judge right from wrong and essentially consider their decisions before committing crimes.

The second form of judgment is the judgment held by the offender's representation. No lawyer can truly be objective. Boyd White explains that there are tensions between the opposing lawyers. Their legal language usage, readings of the law and personal views on justice will all have underlying influence on their actions and in turn, their judgment. ${ }^{9}$

Lastly, there is judgment in sentencing. Klare explains that judges use their imaginations and creativity in judging cases. Without it, law would not develop and will become stagnant. ${ }^{10}$ This creativity however, can lead to possible indeterminacy in judgment.

\section{Public awareness and deterrence}

Information on the illegality of environmental crimes is very easily accessible and should be of vital importance to the citizens of South Africa. Section 21 of the Constitution ${ }^{11}$ states that every South African citizen has the entrenched right to have the environment protected for the benefit of present and future generations.

There are a vast number of statutes such as the Marine Living Resources Act, ${ }^{12}$ the National Environmental Management Act, ${ }^{13}$ and the South African Maritime Safety Authority Act, ${ }^{14}$ which serve in the protection of abalone. The Consumer Protection Act ${ }^{15}$ and the Game Theft Act ${ }^{16}$ give the Environmental Courts provision to issue orders to offenders for damages incurred. The Prevention of Organised Crime $\mathrm{Act}^{17}$ aims at combating and preventing gang and organised crime.

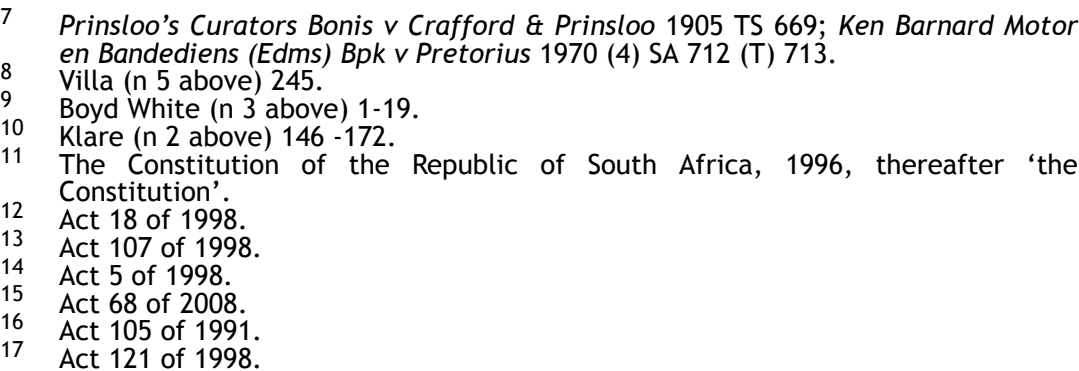


Section 34 of the National Environment Management Act (NEMA) ${ }^{18}$ contains provisions for sentencing offenders and gives the courts power to recover costs needed to rehabilitate the environment.

Every fishing season, permit conditions for abalone fishing are publicly released on the Government of South Africa's website. ${ }^{19}$ Catch limitations, validity of permit, restricted fishing areas and violations, to mention a few, are published in this document. A branch of environmental law serves to protect and enforce the biodiversity of species. Specific Environmental Courts are recognised in terms of section 166 of the Constitution whose function is aimed at charging offenders with environmental crimes.

Abalone (the endemic species haliotis midae) has been listed in Appendix III according to CITES (Convention on International Trade in Endangered Species of Wild Fauna and Flora, 2007). This has been in effect since 3 May 2007. This is made public on the CITES website. The Department of Agriculture, Forestry and Fisheries of South Africa release frequent media statements, where complete updates are provided to the public about arrests, confiscations and sentences given to offenders involved in abalone poaching. ${ }^{20}$

In light of all the protection, legislation and awareness of the illegality of poaching and other environmental crimes, one has to ask: why is there such a recurring problem and why are the deterrence measures not effective enough in order to sustain a healthy and diverse environment?

There is a well-known theory of crime in the field of criminology, known as the 'Rational Choice Theory' by Cornish and Clarke. ${ }^{2 P}$ It proposes that offenders make decisions or choices to commit criminal behaviour, through a process of rationality. They weigh the benefits against the potential consequences. If the benefits seem to outweigh the latter, the probability of choosing to commit the crime increases. I have discussed the consequences in the above paragraphs and I will now cover the potential benefits and the outcomes as a result.

18 Act 107 of 1998.

'Permit conditions: abalone fishery fishing season 2011/2012' found at http:// www.nda.agric.za/doaDev/sideMenu/fisheries/21 Hotlssues/April2010/FishingPe rmitsConditions2012/Abalone\%20Permit\%20Conditions\%20for\%202011_2012\%20sea son.pdf (accessed 31 March 2013).

20 Department of Agriculture, Forestry and Fisheries 'The fight against poaching and corruption shall continue' on 1 August 2012 found at http://www.daff.gov.za/ docs/media/01AUG2012-Anti-PoachingStatement.pdf (accessed 31 March 2013).

21 D Cornish et al The reasoning criminal: rational choice perspectives on offending (1986) 1. 


\section{Benefits or rewards reaped through criminal behaviour}

South Africa is a third world country. There is a large division between rich and poor countries, not only in the standard of living but when you look at the currency value of the country in question. Poaching syndicates' largest target-markets are Asian buyers. The poached stock is usually paid for in dollars. The Rand-Dollar exchange rate is currently at $1 \$=\mathrm{R} 9.98 .{ }^{22}$ This monetary reward will clearly cloud the judgment of an offender's mind when dealing with importing illegal goods - thus making the decision to commit crime an easier one.

To put it into context with regard to abalone poaching, there is a high level of attractiveness in this form of crime. The illicit market for abalone started rising at an incredible rate in the 1990's when the rand started weakening against the dollar. ${ }^{23}$ This may seem irrelevant, but abalone is internationally traded in dollars. This yields high profits for the poachers, when profits are converted back into Rands. A conservative valuation of the South African abalone market price is R350/kg. ${ }^{24}$ Bartering in return for low-priced drugs acquired from the Asian countries (such as methaquolone) also became increasingly common, especially in the Cape Flats drug market. ${ }^{25}$ In 2002 for instance, authorities confiscated more abalone than that collected by commercial fisheries. ${ }^{26}$

\section{$5 \quad$ Explaining motives for criminal behaviour through Arendt's theories of judgment}

The motives of the crime in question can be explained by using Arendt's theory models. The first theory of judgment is largely political and does not have proper relevance to this case study. Arendt's second theory of judgment concerns itself with the linkages between judgment, understanding and thinking. Judgment is seen as a 'component in the life of the mind' the ideas of public policy and universality of ideals and rules are emphasised. ${ }^{27}$ She explains that once rules lose their validity, it becomes difficult to understand or

590 tons of abalone confiscated by South African authorities in 2010 - 2011 9 November 2011, found at http://internationalabalonesociety.org/africa_news. html (accessed 31 March 2013).

Steinberg ( $\mathrm{n} 23$ above) 3.

Steinberg (n 23 above) 1. Villa (n 5 above) 246. 
exercise our judgment accordingly. ${ }^{28}$ Rules only lose their validity if the accepted public standards, morals and ideals so allow.

I believe that this theory relates, in particular to my case study. Abalone poaching is a rising epidemic. It is difficult to deter, or keep record of the numbers and the incidents, if nonchalant attitudes towards protecting endangered species are maintained. This becomes prevalent especially in small coastal towns, where societal attitudes and standards of judgment towards this issue may be negative. It may also be that there is no awareness that the act of poaching is a crime, which hence increases the likelihood of offences. A large problem we are also facing is that there are unknown figures regarding the corruption in the authority, the number of illicit permits out there, or the number of poachers who are practising undetected.

The second point that Arendt makes is that the activity of thinking and judging produces conscience as a byproduct that 'tells' us what is wrong behaviour. ${ }^{29}$ This relates back to my previous notion that it is accepted in the South African legal system, that every individual has a sound mind unless proven otherwise. It can be interpreted in such a way that one can assume that every 'offender' has a sound mind and the predisposition to therefore consider and premeditate their actions beforehand.

Abalone poaching typically takes its form in that of a criminal syndicate. It is well organised and planned. There are three levels of the activity chain in abalone poaching: the divers, the middlemen, who collect the abalone from the divers, and then lastly, the processors, usually the Asian entities who import the abalone stock at a high price. It is evident that serious consideration must be taken before getting involved in such a syndicate.

A troubling question, especially with regard to poaching, is that of 'worth'. With regard to an environmental crime taking place, this is a conscious weighing-up of the worth of money versus the worth of the environment. The former is typically favoured and the potential environmental damages are ignored. According to Arendt, in order for one's judgment to be valid, one must be able to think 'representatively' - from the view of someone else. It can be said that poaching offenders therefore have errors in judgment because of the disregard for the potential consequences that their actions may have on the environment. 


\section{Tensions in law and judgment}

In his work 'Justice in tension: an expression of law and the legal mind', James Boyd White writes that law is not an abstract system, but rather parallels it with the concept of a language - one must work to understand and translate it. ${ }^{30}$

There is a clear power struggle between opposing lawyers in court - both lawyers want to win. ${ }^{31}$ This causes a dynamic tension of thought and action, as lawyers will have, even if it is subconscious, differing moral judgements. Both lawyers will interpret the same set of facts differently, leading to tension arising from the opposing arguments, despite both arguments being premised on the same legal system.

It is for the judge to decide on the outcome of the case, however, judges can never really be completely unbiased and objective in their judgments. In Dugard's 'The judicial process, positivism and civil liberty' he addresses the flaws of positivism. He writes that as long as judicial function is entrusted to men, judgment will never be free of subconscious. ${ }^{32}$

Dugard states that human limitations will always obstruct true judgment and that there will always be a risk of subconscious personal biases, causing tension between the individual and the state. ${ }^{33}$

\section{Case study: S v Barnard}

In the 2005 case, S v Barnard, ${ }^{34}$ the accused was caught pulling bags from the water. He was also discovered to be in possession of bags on the beach containing 666 Abalone. He was accused of three charges: being in possession of abalone without a permit (more than four per day); fishing or collecting abalone during the closed legal season without a permit, and being in custody or in possession of more than 15 abalone at any given time. The accused was only found guilty on the first charge, with the last two being set aside on the basis of redundancy.

The offender was sentenced to a fine of R 40000 or an alternative jail imprisonment of 2 years. The average weight of an abalone, 80 grams, and the conservative market value price of $\mathrm{R} 350 / \mathrm{kg}$, can be used to calculate that the offender would have earned $R 186480 .^{35}$

Boyd White (n 3 above) 1-19.

Boyd White (n 3 above) 1-19.

Dugard (n 4 above) 181-200.

Dugard (n 4 above) 181-200.

S V Barnard $2005 \mathrm{JOL} 14758$ (E).

$0.8 \mathrm{~kg} \times 666 \times \mathrm{R} 350 / \mathrm{kg}=\mathrm{R} 186480$ 
This is disappointing, as the fine imposed on the offender was almost 5 times less than the potential revenue that would have been received from the sale of the illegal abalone. Further, the accused would likely have sold it to an international buyer paying in dollars, proving even more lucrative.

I believe that such a fine does not serve as a sufficient deterrence, thus contributing to higher recidivism rates. Boyd White explains that with regard to the judgment, there is tension between the different readings of the law. Judges have tension in their mind where they must make their own choice of judgment, whether it be making a choice over sentencing or a penalty fine. Thereafter, they must accept responsibility for it. The tension between law and justice will never be perfect. One of the two will never be fully met and fulfilled. ${ }^{36}$

\section{Conclusion}

In conclusion, I argue that large monetary benefits definitely surpass the criminal sanctions in the judgement of an offender thereby resulting in the commission of crime. that are imposed by the law. By consequence, I argue that considerations for the law or the environment are too surpassed. Human judgment is flawed, whether it is the judgment belonging to a civilian, a criminal or even a judge. It is prevalent in all. It rests on the willpower of the individual on whether to exercise freedom or constraint. 